\title{
Ewa Danowska*
}

\section{Jana Miłoszewskiego dobytek doczesny. Inwentarz pośmiertny małopolskiego szlachcica z $1725 \mathrm{r}$.}

Inwentarz sporządzony po zmarłym w 1725 r. Janie Miłoszewskim, skarbniku ciechanowskim i komorniku granicznym powiatu krakowskiego, stanowi ciekawy dokument jako przykład pośmiertnego spisu ruchomości małopolskiego szlachcica epoki saskiej - jego stanu posiadania i przez to pośrednio pozycji wśród szlachty. Znaleźć można w nim ponadto pewne fakty dotyczące życia rodzinnego związane z koniecznością sporządzenia inwentarza. $Z$ tych powodów wydaje się wart publikacji.

Poza testamentem, którego przygotowanie każdy prawy chrześcijanin poczytywał sobie za obowiązek, równie ważne było sporządzenie inwentarza pośmiertnego, gdy właściciel majątku przeniósł się do wieczności. Ten akt, mający również aspekt prawny, ostatecznie porządkował jego ziemskie sprawy. Inwentarz to wszak rejestr, a jak określono w XVI w. - ,urzędne popisanie rzeczy nalezionych na dziedzictwie abo w pomieszkaniu zmarłego lub dłużnika"1, co przypomniał Zygmunt Gloger.

Inwentarze pośmiertne należą do najlepszych i najbardziej drobiazgowych źródeł, jakimi dysponuje historyk w celu odtworzenia stanu posiadania ludzi w przeszłości. Żaden inny przekaz nie przynosi tak wiernego obrazu domowej codzienności. Inwentarze były spisywane dla potrzeb spadkowych, zwłaszcza gdy po zmarłym zostawały małoletnie dzieci, których przyszły dobytek należało zabezpieczyć, lub gdy rodzina nie mogła dojść do porozumienia przy podziale spadku².

* historyk, dr hab., starszy kustosz dyplomowany, Biblioteka Naukowa PAU i PAN w Krakowie, Dział Zbiorów Specjalnych, Pracownia Rękopisów; zainteresowania badawcze: historia Polski XVIII i XIX w., dzieje Krakowa, biografistyka, edytorstwo źródeł; e-mail: ewa.lidia.danowska@gmail.com; ORCID ID: 0000-0002-3273-4020

${ }^{1}$ Inwentarz, [w:] Zygmunt Gloger, Encyklopedia staropolska ilustrowana, t. 2, Warszawa 1901, s. 276.

${ }^{2}$ Elżbieta Kowecka, Inwentarze pośmiertne, „Mówią Wieki” 1988, nr 10, s. 9. 
Sporządzano go skrupulatnie, niczego nie pomijając, o czym zapewniano w dokumencie, mimo iż - co również zaznaczano - niektóre rzeczy lub sprzęty były stare, zepsute lub zużyte. Jego rzetelność nie mogła budzić wątpliwości. Często na początku lub na końcu umieszczano zapewnienia, że spis został sporządzony zgodnie z zastaną sytuacją. Co prawda, zawsze istniała możliwość deformacji stanu faktycznego, np. poprzez zatajenie istnienia pewnych przedmiotów, $\mathrm{z}$ drugiej jednak strony $\mathrm{w}$ interesie spadkobierców było, by nie pominięto niczego, co im się należało ${ }^{3}$.

Wskazówki dla inwentaryzujących mienie opracował m.in. Adam Volckmann, znawca prawa żyjący w Saksonii na początku XVII w. Radził, które dobra powinny być odnotowane $w$ inwentarzu. Za najważniejsze uważał nieruchomości, po czym - jak pisał - należało odnotować „mobilia”, wśród nich gotówkę, srebrne naczynia, klejnoty, odzież, zbroje i oręż, cynę, mosiądz, miedź, obrazy, sprzęty domowe i inne. Kolejną pozycję spisu powinny stanowić zwierzęta domowe (bydło, konie, świnie, owce, kozy czy drób), trzeba było także uwzględnić zapasy wina i piwa w piwnicy oraz zboże w stodole i na polu. Spis miały zamykać informacje o skryptach dłużnych, depozytach czy należnych prawach, np. do czynszu ${ }^{4}$. Badania prowadzone nad staropolskimi inwentarzami pośmiertnymi potwierdzają, że wskazówki A. Volckmanna były stosowane w praktyce. Dodać można, iż takie spisy ujmowały także np. koński rynsztunek, utensylia kuchenne, narzędzia gospodarcze czy zawartość domowej biblioteki ${ }^{5}$.

W przypadku edytowanego inwentarza pośmiertnego J. Miłoszewskiego wdowa po nim - zanim inwentarz wpisano do akt sądowych grodzkich krakowskich - zdążyła już po raz kolejny wyjść za mąż. Według obowiązującego prawa, po śmierci męża dobra pochodzące $z$ wiana, a także posagu wraca-

${ }^{3}$ Mirosława Gajewska, Wyposażenie w sprzęty mieszczańskie gospodarstw domowych Poznania i Warszawy w XVIII wieku, Studia i Materiały z Historii Kultury Materialnej t. 50, Wrocław, 1975, s. 147-148; Elżbieta Kowecka, Mieszkania warszawskie w XIX wieku (do 1870 r.), [w:] Elżbieta Balcerzak, Elżbieta Kowecka, Jerzy Kruppé, Wybrane problemy kultury materialnej miast polskich w XVIII i XIX wieku, Studia i Materiały z Historii Kultury Materialnej t. 56, Wrocław, 1983, s. 16.

4 Andrzej Klonder, Mienie godne szlachcica $i$ mieszczanina $w$ krajach Europy Środkowej z XVII wieku, „Kwartalnik Historii Kultury Materialnej” 2001, R. 49, nr 1-2, s. 81-82.

${ }^{5}$ Andrzej Pośpiech, Pułapka oczywistości. Pośmiertne spisy ruchomości szlachty wielkopolskiej z XVII wieku, Studia i Materiały z Historii Kultury Materialnej t. 64, Warszawa, 1992, s. 110. 
ły do wdowy. Reszta majątku należała się dzieciom lub krewnym zmarłego męża. W praktyce nie zawsze było to przestrzegane, a wdowa mogła liczyć na więcej z majątku po zmarłym, niż zapisano w przepisach prawnych. Dochodziło do prywatnych układów, gdyż w rzeczywistości podział ruchomości i nieruchomości między wdowę a spadkobierców męża rozpatrywano zależnie od sytuacji, a ustawy starały się wprowadzić tylko pewne stałe prawidła. Można dodać, że wdowa, która powtórnie wychodziła za mąż, traciła prawo do opieki nad małoletnimi dziećmi pochodzącymi z poprzedniego małżeństwa, a co za tym idzie - do dysponowania ich majątkiem ${ }^{6}$. Miała natomiast zagwarantowane prawo w imieniu małoletnich dzieci do zarządu majątkiem po mężu. Jak już wspomniano, dziedziczenie rzeczy ruchomych nie było przedmiotem większego zainteresowania ówczesnego prawa, które całą uwagę skupiało na nieruchomościach. Ruchomościami zajmowano się głównie przy podziale majątku między spadkobierców a wdowę 7 .

Inwentarze pośmiertne sporządzano w całej Europie. Raimo Pullat zauważa, że pod względem budowy i struktury można je podzielić na dwa typy. Pierwszy był charakterystyczny dla krajów niemieckich, Polski, Szwecji czy terenów obecnych krajów nadbałtyckich - inwentarze sporządzano tam, biorąc pod uwagę kategorie przedmiotów. Natomiast np. w Anglii, Francji i w Niderlandach przedmioty w wykazach mienia są pogrupowane według pomieszczeń, w których się znajdowały ${ }^{8}$. Inwentarz pośmiertny J. Miłoszewskiego, potwierdza tę regułę, charakterystyczną m.in. dla polskich ziem.

Niejednokrotnie inwentarz pośmiertny stanowił integralną część testamentu - wtedy ostatnia wola była dyspozycją majątkiem, a inwentarz konkretnym spisem, określającym jednocześnie jego wartość. Zaznaczyć należy, iż drobiazgowość i staranność wykonania inwentarzy pośmiertnych bywały różne, co nie tyle zależało od zamożności nieboszczyka, co raczej od skrupulatności spisujących jego dobytek ${ }^{9}$.

${ }^{6}$ Ibidem, s. 420-421, 425-431.

${ }^{7}$ Juliusz Bardach, Historia państwa i prawa Polski, t. 1: do połowy XV wieku, Warszawa 1964, s. 507, 509.

${ }^{8}$ Raimo Pullat, Świat rzeczy mieszkańca Tallina w dobie Oświecenia, Kraków 2018, S. 25.

${ }^{9}$ Ewa Danowska, O rzeczach doczesnych księdza kanonika. Inwentarz pośmiertny Michała hrabiego Ankwicza z 1786 r., „Nasza Przeszłość. Studia z dziejów Kościoła i kultury katolickiej w Polsce” 2008, t. 110, s. 107-108. 
Sporządzenie inwentarza było istotne przede wszystkim dla spadkobierców mienia, ponieważ, jak zauważył Bartłomiej Groicki - odnośnie co prawda do inwentarzy mieszczańskich, lecz zasadę tę przyjmowano też w prawie dotyczącym stanu szlacheckiego - chronić miało spadkobiercę przed wygórowanymi pretensjami ewentualnych wierzycieli, mogły one wszak dotyczyć tylko dóbr pozostawionych przez zmarłego. Uważano również, że tylko ten kto sporządził solidny inwentarz spuścizny, był w stanie sumiennie rozliczyć się z zarządzania cudzym mieniem ${ }^{10}$.

$\mathrm{Na}$ podstawie inwentarzy pośmiertnych można uzyskać dane o wielu dziedzinach produkcji i konsumpcji, ale też warto uznać je za pewną informacyjną całość świadczącą o zamożności jednostek i zbiorowości - rodzin, stanów i społeczności. Służą także do badań nad poziomem i rozwojem cywilizacyjnym w zakresie kultury materialnej ${ }^{11}$.

Pośmiertny spis ruchomości, czyli inwentarz, jest zatem istotny dla badań nad kulturą materialną danej epoki i danej warstwy społecznej. Pozwala zapoznać się ze szczegółami niedostępnymi w innych rękopiśmiennych źródłach, które nie ukazują codzienności w prozaicznych, materialnych przejawach. Można dodać, że najstarsze zachowane inwentarze pośmiertne pochodzą z XIV-wiecznej Burgundii, a rozwój tych źródeł w Polsce zapoczątkowany został w XVII w., by osiągnąc rozkwit w XVIII w. ${ }^{12}$

W polskim prawie dotyczącym zarówno warstwy szlacheckiej, jak i mieszczańskiej ustalone zostały pewne regulacje związane ze sposobem spisywania inwentarzy, zwłaszcza przy obejmowaniu opieki i spadku. Przepisy te odnosiły się przeważnie do czasu i sposobu, w jaki należało sporządzić dokument, np. konieczność spisania go w obecności krewnych, świadków lub wobec delegata władzy sądowej. Wskazania tego typu miały na celu zabezpieczenie praw spadkobierców i zapobieganie możliwym nadużyciom. Inwentarze wpisywano do odpowiednich ksiąg sądowych ${ }^{13}$. Spisywano w nich rzeczy ruchome i nieruchome w znaczeniu prawnym. Na przykład dziesięć koni uznawano za rzecz ruchomą, a powyżej dziesięciu było już stado, które uważano za rzecz nieruchomą. Podział taki stosowano także

${ }^{10}$ Andrzej Klonder, Wszystka spuścizna w Bogu spoczywajacego. Majątek ruchomy zwyktych mieszkańców Elblaga i Gdańska w XVII wieku, Studia i Materiały z Historii Kultury Materialnej t. 68, Warszawa 2000, s. 8-9.

${ }^{11}$ Ibidem, s. 7.

${ }^{12}$ A. Pośpiech, Pułapka oczywistości..., s. 7-16.

${ }^{13}$ Przemysław Dąbkowski, Prawo prywatne polskie, t. 1, Lwów 1910, s. 242. 
do sum pieniężnych, np. kwota do dziesięciu grzywien stanowiła rzecz ruchomą, natomiast powyżej tej sumy - nieruchomą ${ }^{14}$.

Niestety nie zachowało się wiele informacji na temat życia J. Miłoszewskiego. W dokumencie określony jest jako pan na Miłosławiu i Zielonej. Niewykluczone, że jego rodzina wywodziła się z miejscowości Miłoszowiec na Mazowszu, na co wskazywałby tytuł Miłoszewskiego - skarbnika ciechanowskiego. Natomiast Zielona to zapewne wieś wówczas w powiecie krakowskim, obecnie proszowickim ${ }^{15}$.

O J. Miłoszewskim nie ma wiadomości w herbarzach poza krótką wzmianką w Rodzinie Seweryna Uruskiego: „Jan, syn Dominika i Elżbiety, komornik 1719, następnie skarbnik ciechanowski 1728 [sic!]"16. Uruski podaje jego herb: Leszczyc ${ }^{17}$, a nazwisko w zapisie nieco innym niż w publikowanym poniższej dokumencie, a mianowicie: Miłaszewski, nie Miłoszewski. Nazwisko Miłoszewskiego na początku inwentarza pośmiertnego występuje z tytułem skarbnika ciechanowskiego. Była to najniższa funkcja w hierarchii urzędników ziemskich ${ }^{18}$. Zajmował też stanowisko komornika granicznego powiatu krakowskiego, a został nim ustanowiony przez króla Augusta II Sasa w Kliszowie 10 czerwca 1713 r. ${ }^{19}$

Należy dodać, iż podkomorzy danego województwa czy ziemi posiadał prawo mianowania komorników jako swych pomocników w prowadzeniu sporów i spraw granicznych. Pochodzili oni wyłącznie ze szlachty osiadłej i składali przysięgę taką samą jak podkomorzowie. Z czasem ich liczba zwiększała się - od drugiej połowy XVII w. pojawiali się komornicy graniczni dla poszczególnych powiatów sądowych. Komornik danego powiatu w imieniu podkomorzego prowadził wszelkie czynności „na gruncie”, gdzie przyjeżdżał w związku z prowadzonym procesem. Sporządzane przez geo-

${ }^{14}$ Ibidem, s. 246-247.

${ }^{15}$ Stownik geograficzno-historyczny Królestwa Polskiego i innych krajów słowiańskich, t. 14, red. Bronisław Chlebowski, Józef Krzywicki, Filip Sulimierski, Warszawa 1895, s. 596.

${ }^{16}$ Sew eryn Uruski, Rodzina. Herbarz szlachty polskiej, t. 11, Warszawa 1914, s. 88.

${ }^{17}$ Ibidem, s. 88.

${ }_{18}$ Zbigniew Góralski, Urzędy i godności w dawnej Polsce, Warszawa 1984, s. 187, 204.

${ }^{19}$ ANK, Księgi grodzkie krakowskie, sygn. 29/5/800, s. 551-552. 
metrów mapy służyły komornikom granicznym jako pomoc w przeprowadzaniu służbowych czynności, np. rozgraniczeń ziemi ${ }^{20}$.

W księgach sądu podkomorskiego zachowały się liczne wpisy świadczące o aktywności J. Miłoszewskiego jako komornika granicznego na terenie powiatu krakowskiego, pochodzące z lat 1720-1724. I tak: pracował niejednokrotnie przy ustalaniu granic dóbr szlacheckich Brzezna i Wygnanów, wsi Dąbrowa z Dolnymi i Górnymi Lusławicami, wsi Lubienia sive Lubinka, między wsiami Tczyca a Wierzbie, a także w dobrach Akademii Krakowskiej Bronowice, Krowodrza i Tonie, następnie granicy dóbr królewskich Pierzchów ze szlachecką Cichawą, Pruszkowem oraz Książnicami, ponadto brał udział w rozgraniczaniu wsi Barczków i Popędzyna ${ }^{21}$.

J. Miłoszewski, stosownie do swego statusu społecznego, zapewne często uczestniczył w różnego rodzaju szlacheckich sejmikach. Na przykład odnotowano, iż na sejmiku proszowickim 29 lipca 1716 r. podczas nieobecności zajętego działaniami zbrojnymi marszałka krakowskiego, chorążego łomżyńskiego Marcina Rybińskiego, skarbnikowi ciechanowskiemu J. Miłoszewskiemu powierzono przewodniczenie temu sejmikowi ${ }^{22}$.

Wiadomości dotyczące rodziny J. Miłoszewskiego są bardzo skąpe. Pozostała po nim wdowa Elżbieta z Trzebini $1^{\circ}$ v. Butakowska. Szybko też po śmierci J. Miłoszewskiego wyszła za mąż po raz kolejny za Władysława z Lubieńca Lubienieckiego, komornika granicznego powiatu sądeckiego.

Inwentarz dóbr pozostałych po J. Miłoszewskim został spisany w Łazach, wsi znajdującej się wówczas w powiecie krakowskim, 6 marca 1725 r. Porównując go np. z dokumentami dotyczącymi szlachty krakowskiej, nie można J. Miłoszewskiego zaliczyć do ludzi ubogich. Spis jego ruchomości świadczy o gromadzeniu dóbr w rodzinie przez pokolenia. Niewątpliwie oprócz pełnienia odpowiedzialnej funkcji komornika ziemskiego zajmował się również własnym majątkiem.

Także rzemiosło wojenne nie było mu obce, skoro w księgach grodzkich znalazł się wpis z 17 lutego 1717 r. dotyczący delaty kwot należących się

${ }^{20}$ Janina Mirosława Stoksik, Geometrzy małopolscy do końca XVIII wieku. Z dziejów geodezji i kartografii wielkoskalowej w Polsce, Kraków 2013, s. 45, 48, 53.

${ }^{21}$ ANK, Księgi sądu podkomorskiego, sygn. 29/18/8, s. 24-30, 43-60, 74-108, 117-121, 125-146, 162-169; sygn. 29/18/9, s. 71-82, 85-91, 109-111, 113-124, 149-151, 157-165, 179-181, 193-194, 347-356.

${ }^{22}$ Wojciech Kriegseisen, Samorzad szlachecki w Małopolsce w latach 1669-1717, Warszawa 1989, s. 151. 
chorągwi pancernej J. Miłoszewskiego ${ }^{23}$. Broń służyła mu też zapewne z racji wykonywanego zawodu - komornicy graniczni byli narażeni na różne niebezpieczeństwa. W inwentarzu pośmiertnym wyszczególniono znaczną ilość broni palnej i białej oraz rzędy końskie, ponadto wymieniona została broń o charakterze paradnym.

J. Miłoszewski posiadał w domu dość obszerną jak na owe czasy biblioteczkę złożoną z pięćdziesięciu pięciu ksiąg i trzech manuskryptów. Jak można sądzić ze spisu, niewykluczone, że w głównej mierze odziedziczoną po przodkach. Obejmowała ona księgi o różnorodnej tematyce, głównie prawniczej (polskie konstytucje sejmowe i statuty), ale też historycznej czy religijnej. Przy niektórych egzemplarzach opisano wygląd danej książki i nierzadko charakter częstych defektów i zniszczeń, a jej autora lub tytuł potraktowano marginalnie, co obecnie utrudnia precyzyjną identyfikację danej pozycji.

Można przypuszczać, że J. Miłoszewski wiele uwagi poświęcał prowadzeniu prywatnych spraw sądowych, czego dowody znajdują się w jego inwentarzu. Widnieje tam zapis, iż pewne konie z jego stadniny trafiły w ręce patrona lubelskiego i patrona krakowskiego, których nazwiska trudno dziś ustalić, być może jako zapłata za świadczone usługi prawne. W inwentarzu pośmiertnym nie ma zbyt wielu informacji o rodzinie J. Miłoszewskiego, co nie powinno dziwić w przypadku inwentarza. Jest jednak wzmianka o panu Miłoszewskim, staroście kleszczowskim, któremu wdowa dostarczyła konia. W innym miejscu wymieniony jest Adam Miłoszewski, który sobie wziął kulbakę, a także nieznany z imienia syn, który używa srebrnej karabeli, a także jeździ na ślepym koniu srokatym. Niestety nie wiadomo, czy to syn Miłoszewskich, czy z poprzedniego małżeństwa Elżbiety.

Na początku publikowanego inwentarza znajduje się dział ,pieniądze”wymieniono tu gotówkę, ale także srebrne wyroby, jak tace, lichtarze, czarki, sygnety i guziki, mające wymierną wartość w pieniądzach. Wyszczególnione w następnej kolejności przedmioty są ściśle związane z trybem życia, funkcją i pozycją społeczną J. Miłoszewskiego - moderunek, szable, kulbaki i strzelby. Podano ich charakterystykę, co przyczynić się może do badań nad kulturą materialną ówczesnej epoki, podobnie jak opisane przedmioty z cyny, miedzi, mosiądzu czy pozostałe sprzęty domowe lub te służące w gospodarstwie. Wyliczony tu inwentarz żywy jest wyraźnie podupadły,

\footnotetext{
${ }^{23}$ ANK, Księgi grodzkie krakowskie, sygn. 29/5/805, s. 326-327.
} 
skrupulatnie bowiem wymieniono zwierzęta padłe lub podarowane z różnych powodów. Warto zaznaczyć, że poszczególne pozycje inwentarza nie zostały oszacowane - nie podano ich wartości w pieniądzach ${ }^{24}$.

Inwentarz majątkowy, chociaż z pozoru sprawia wrażenie nużącego w lekturze spisu przedmiotów, dostarcza wielu informacji o konkretnym człowieku, jego stanie zamożności, statusie czy aspiracjach ${ }^{25}$. To swoista „opowieść o ludziach i rzeczach”26 - jak stwierdził Andrzej Pośpiech.

Podczas edycji przyjęto zasady Instrukcji wydawniczej dla źródel historycznych od XVI do połowy XIX wieku ${ }^{27}$. Ortografia i interpunkcja tekstu zostały uwspółcześnione, zachowano natomiast staropolskie cechy języka i jego fonetykę, np. niebosczyk, kiliszek, kozaczkie, z herbamy, z uszkamy, mosztuk, gołka, książecka, materacz, połomany, barzo i in. W tekście nie zastosowano żadnych skrótów, podając zapis w pełnym brzmieniu, np. Pan czy Jegomość, podobnie zostawiono słowny zapis liczebników.

Nazwy i wtręty w języku łacińskim zostały przetłumaczone w przypisach. W przypadku książek wyszczególnionych w inwentarzu pośmiertnym starano się ustalić autorów, tytuły oraz miejsce i rok wydania na podstawie bibliografii drukowanych, przede wszystkim Karola Estreichera ${ }^{28}$, a także bazy NUKAT i Karlsruher Virtuell Katalog (KVK). Niestety w wielu przypadkach identyfikacja była niemożliwa ze względu na skrótowy zapis lub potoczne określenie danej pozycji, trudne obecnie do weryfikacji. Na końcu tekstu dołączono słowniczek wyrazów staropolskich i rzadziej używanych. Do jego wykonania wykorzystano: Stownik języka polskiego ${ }^{29}$, Encyklope-

${ }^{24}$ Por. np. większość inwentarzy w: Inwentarze mieszczańskie z wieku XVIII z ksiag miejskich i grodzkich Poznania, t. 1: z lat 1700-1758, oprac. Józef Burszta, Czesław Łuczak, Poznań 1962.

25 Ewa Danowska, Inwentarz pośmiertny rajcy krakowskiego Andrzeja Stanisława Krauza z 1702 r., „Rocznik Krakowski” 2007, R. 73, s. 95; eadem, Intercyzy, testamenty i inwentarze pośmiertne krakowskich mieszczan epoki nowożytnej jako źródło edycji, [w:] Teoria i praktyka edycji nowożytnych źródet w Polsce (XVI-XVIII w.), red. Adam Perłakow ski, Kraków 2011, s. 220-221.

${ }^{26}$ A. Pośpiech, Pułapka oczywistości..., s. 9.

${ }^{27}$ Instrukcja wydawnicza dla źródeł historycznych od XVI do połowy XIX wieku, red. Kazimierz Lepszy, Wrocław 1953.

${ }^{28}$ Karol Estreicher, Bibliografia polska (stulecie XV-XVIII w uktadzie abecadtowym), Warszawa 1977.

${ }^{29}$ Słownik języka polskiego, red. Jan Karłowicz, Adam Kryński, Władysław Niedźwiedzki, t. 1-8, Warszawa 1952-1953. 
dię staropolska ilustrowana ${ }^{30}, 1000$ stów o broni i balistyce ${ }^{31}, 1000$ słów o broni białej i uzbrojeniu ochronnym ${ }^{32}$ oraz Stownik ubiorów $w^{33}$.

\section{TEKST ŹRÓDLOWY ${ }^{34}$}

Inwentarz rzeczy ruchomych i nieruchomości, po śmierci Jana Miłoszewskiego, do ksiąg grodzkich krakowskich przynieśli: Józef z Michałowa Michałowski ${ }^{35}$ i Antoni z Glendzianowa Bełchacki ${ }^{36}$, w towarzystwie Elżbiety z Trzebini, $1^{\circ}$ v. Butakowskiej, $2^{\circ}$ v. Miłoszewskiej, obecnie żony Władysława z Lubieńca Lubienieckiego.

Kopia. Oryginał wpisany do ksiąg po dacie 25 II 1725 r. [sic!].

[s. 665] Inwentarz rzeczy ruchomych niżej specyfikowanych, po śmierci [s. 666] Wielmożnego Jegomości Pana Jana na Miłosławiu i Zielonej Miłoszewskiego skarbnika ciechanowskiego, komornika granicznego powiatu i województwa krakowskiego pozostałych, przeze mnie z Trzebieni Elżbietę powtórnią małżonkę jego a teraźniejszą Lubieniecką spisany i ręką moją własną podpisany w Łazach dnia szóstego miesiąca marca Roku Pańskiego tysiącznego siedemsetnego dwudziestego piątego.

\section{Pieniądze}

Zostało się gotowych pieniędzy aureas numero ${ }^{37}$ jedenaście, srebro ze złotem dwie, czary z talerami wprawionemi, te są in pignus ${ }^{38}$ dane nieboszczykowi przeszłemu mężowi memu godnej pamięci Jegomość Panu Miłoszewskiemu (o czym karta szerzej opiewa).

Taczek srebrnych numero $^{39}$ dwie gotowalnianych białych, jednakowych dico ${ }^{40}$ dwie

Taczka biała z uszema złocistemi także gotowalniana

30 Zygmunt Gloger, Encyklopedia staropolska ilustrowana, t. 1-4, Warszawa 1900-1903.

${ }^{31}$ Stanisław Torecki, 1000 stów o broni i balistyce, Warszawa 1982.

${ }^{32}$ Włodzimierz Kwaśniewicz, 1000 słów o broni białej i uzbrojeniu ochronnym, Warszawa 1981.

${ }^{33}$ Irena Turnau, Stownik ubiorów. Tkaniny, wyroby pozatkackie, skóry, broń i klejnoty oraz barwy znane w Polsce od średniowiecza do poczatku XIX w., Warszawa 1999.

${ }^{34}$ ANK, Księgi grodzkie krakowskie, sygn. 29/5/817, s. 665-674.

35 Józef Antoni Michałowski (syn Melchiora), starosta różański, podstarości i sędzia grodzki krakowski 1720-1741, podstoli krakowski 1720-1735, chorąży krakowski od 1735 r. Zmarł przed 9 lutego $1743 \mathrm{r}$.

${ }^{36}$ Antoni Bełchacki, pisarz grodzki krakowski 1718-1728, cześnik krakowski od 1720 r. Zmarł przed 17 sierpnia $1731 \mathrm{r}$.

${ }^{37}$ Aureas numero - złotych dokładnie.

${ }^{38}$ In pignus - w zastaw.

${ }^{39}$ Numero - dokładnie.

${ }^{40}$ Dico - słownie. 
Tacz dwie białych jednakowych z herbami nieboszczyka męża mego przeszłego nowo sporządzonych, do których przerobienia i ja srebrem moim własnym dokładałam się z częścią przetopionych koron srebrnych Franc Libru ${ }^{41}$ częścią kawałkami różnego srebra i od roboty tych taczek własnym moim groszem zapłaciłam Panu Ceyplerowi ${ }^{42}$ złotnikowi krakowskiemu.

Lichtarzyków para białych srebrnych

Lichtarzy para okrągłych staroświeckich gładkich

Czarka jedna srebrna z uszkamy

Czareczka mała srebrna do wotki [sic!] picia

Łyżek srebrnych kopytkowych dwanaście z herbamy Nieboszczyka męża mego, do których przerobienia łyżek i ja swego srebra dokładałam

Dwie kozaczkie łyżki

Łyżka blachmalowa do której są grabki srebrne składane

Guzów wielkich z rubinami sześć

Złotych guzików pomniejszych złocistych ośmnaście, w których są szmaragdy [s. 667] i rubinki

Guzików sześć złocistych w których jest po rubinku jednym

Sygnet z krwawnikiem złocisty w których jest dyjamentów jedenaście

Sygnet z krwawnikiem koło którego jest smaraszków dwanaście

Sygnet z błękitnym kamieniem, koło niego rubinków sześć

Spinka rubinowa w której rubinków sześć

Moderunek

Jedna ładownica na czapie białej sadzona koralamy i turkusikami

Druga ładownica na czapie czarnej sadzona pięcią koralamy rzniętemu

U obu ładownic taśmy jedwabne złotem przerabiane z kutasamy

Jedna szabla złocista barzo wytarta

$$
\text { Szable }
$$

Karabela jedna złocista w rysowaniu blachmal się przewija, sadzona rubinkami małemy i aspiżkamy, a raczej turkusikami, w niektórych miejscach kamyki powypadały

Rękawice aspisowa stuczona

Paski jedwabne karmazynowe, na końcu do zamykania zakliki srebrne, w nich rubinki są

Szabla w której głownia tureczka w oprawie żelaznej, świątnicką robotą ${ }^{43}$ pochwy złomane

Bez pasków karabela srebrna pozłocista której syn zażywa

${ }^{41}$ Franc Libru - prawdopodobnie korony srebrne bite na stopę francuską, francuskie Ecu.

${ }^{42}$ Złotnik krakowski Ceypler - prawdopodobnie Jan Ceypler, który m.in. w 1695 r. wykonał relikwiarz na głowę św. Jana Kantego. Miał syna Kazimierza, też złotnika. Zob. Leonard Lepszy, Cech złotniczy w Krakowie, „Rocznik Krakowski” 1898, R. 1, s. 163, 184, 228.

${ }^{43}$ Świątniki Górne - wieś w pow. wielickim. Rozwijało się tam rzemiosło, przede wszystkim ślusarskie. 
Szabla srebrna złocista in recompensam ${ }^{44}$ prac i fatyg Jegomości Panu patronowi lubelskiemu ${ }^{45}$ ofiarowana

Pałasz jeden prosty z munsztukiem srebrno złocistym, na kapturku kamień czerwony rznięty bez pasków

Saydak czerwono juchtowy, pstro złocisty sadzony turkusamy, pas przy nim suto złocisty z kruczkiem do niego

Misurka złocista turkusamy i szczepcem sadzona, do którego saydaku karwasze blachmalowe srebrne z sztuczkami złocistemy

Saydak drugi na czerwonym juchcie biało dublerowany, srebrny z paskiem suto srebrnym białym, do niego denko blachmalowe do misiurki bez czepca, do którego karwaszów para oprawnych w srebro i z łapciamy

Strzały w sepeciku sukiennym sznurowanym

Pancerz jeden wenecki bez srebra wychędożony

Jeden rząd husarski suto złocisty, to jest nadgłówek z czepcem i z uzdzieniczką, w nim kamień zabieniec nazwany z podpierścieniem [s. 668] gdzie także kamień drugi zabieniec

Jeden dywdyk turecki w pasy zażywany z frandzlą

Jeden rządzik czerkieski sztuczkamy srebrnemy przerabiany na rzemieniu starym błękitnym

Rządzik sproty w którym cyfra srebrna wybijana pozłocista

Gałka [gałek] do szyje sztuczek pomniejszych numero ośmdziąt cztery

Kawałków srebra do tegoż rządzika należących dwadzieścia ośm

Pasek do saydaka srebrny pozłocisty w których jest sztuczek piętnaście korali, w tych sztuczkach dziewiętnaście sztuczek różnych małych dziewiętnaście srebrnych między niektórymi i korale pomniejsze znajdują się

Sztuczek różnych małych dwieście szesnaście insuper ad complementum ${ }^{46}$ wyżej specyfikowanych guzików, guziczków małych pozłocistych piętnaście

Mosztuk na konia żelazny jeden

\section{Kulbaki}

Kulbaka jedna na suknie czerwonym srebrem awtowana z obwotką srebrną, woyłok z płatem zły stary

Druga kulbaka z obwódką srebrną nadpsuwana, pokryta skórką niemcową czerwona, woyłok do niej stary zły, płat habowy zły stary

Kulbaki cztery stare złe czeladne bez potrzeb, woyłoki do nich złe, na nic się nie przydadzą

Kulbaka piąta co ją wziął Jegomość Pan Adam Miłoszewski ze wszytkiemi potrzebami

Łęk nowy który w zasługach wziął Pan Łęcki

Troje juków zażywanych, starych, podróżnych na konie podwodne

Czwarte maleńkie, deków dwa, czerwone, stare na konie

Skórków dwie czarnych do płatów

\footnotetext{
${ }^{44}$ In recompensam - w wynagrodzeniu.

${ }^{45}$ Patron lubelski - obrońca w Trybunale Głównym Koronnym powstałym w 1578 r. Był to najwyższy sąd apelacyjny dla spraw prawa ziemskiego.

${ }^{46}$ Insuper ad complementum - u góry, powyżej dopełnienie.
} 
Burka biała bez podszycia

Buzdyganik żelazny drdzą [sic!] zepsowany

\section{Strzelba}

Pistoletów z mosiężnemi kapturkami, rury szmelcowane para jedna

Pistoletów bilskich rury rysowane od zapału

Druga para sztuciec gwintowy w którym gwintów jest dwanaście

Jeden muszkiecików gwintowych z których w każdym z osobna jest po gwintów ośm, na zamkach blachy mosiężna

Para jedna muszkiecików pomniejszych w prostej oprawie, zamki proste, w każdym po gwintów dwanaście

Para jedna szturmaków w orzech oprawnych jednakowych, zamek u jednego zepsowany

[s. 669] Para jedna szturmak turecką robotą - kością i macicą perłową nasadzany jeden, do tych szturmaków do noszenia pasów dwa rzemiennych

Fuzyja jedna z dwiema rurami przykład mosiądzem nabijany

Gałek parzystych teczka, robotą prostą para jedna

Muszkiet jeden z kozackim zamkiem

Muszkiecik goły zły

Fuzyjka na ptaki w złej osadzie

Działko mosiężne jedno na żelaznym lawecie

Multan jeden ${ }^{47}$

Działek większych żelaznych na kółkach okowanych para jedna

Działek pomniejszych żelaznych kółka nieokowane para druga

Moździeżów starych żelaznych cztery

Hakownice dwie złe

Dzierytki trzy

Róg do prochu bawoli czarny

Prochownica kościana biała na której jest herb Męża mego Niebosczyka

Prochownica mała

$$
\text { Cyna }
$$

Misterniejszą modą głębokich [talerzy] u których są kraje rysowane bez herbu dwie numero

Mis z szerokiemi krajami numero trzy bez herbu

Półmisków pomiernych jednakowych bez herbu cztery

Talerzy cynowych dwanaście, bez herbu sześć, z herbami sześć

Talerzy zimowych dwa ze śrubkami

Prawd cynowych numero siedm

Salserka do stołu okrągła o czterech kubeczkach na korzenie

Jedna taczki do podawania kiliszków z herbami niebosczykowskiemi

Dwie czarki - jedna cynowa

Lichtarzyków cynowych par dwie

${ }^{47}$ Multan - broń biała (zob. Słowniczek wyrazów staropolskich i rzadziej używanych); tu: omyłkowo wymieniona wśród broni palnej. 
Flasz trzy półgarncowych z śrubami cynowych

Puzdro w którym jaszcz cynowy ze dwiema talerzamy i przystawek dwie i półmisek na wierzchu u którego puzdra po rogach jest flaszek cynowych cztery

\section{Miedź}

Półmisków miedzianych już dobrze zażywanych ośm

Talerzy miedzianych także zażywanych dziesięć

Talerzy blaszanych zażywanych trzy

Misa już także zażywana jedna na to naczynie jest puzdro i z wierzchem miedziane

Garczków miedzianych dwa większych, dwa pomniejszych, w których nie masz kwart trzech już dobrze zażywanych

Wanienka mała dla wody do flasz wstawienia

Flasza miedziana, garcy w niej półpięta ze śrubą

Flaszek pięć miedzianych półgarncowych już dużo napsowanych [s. 670] na które puzderka skórą obite ze wszytkiem

Kusze dwa wielkie miedziane zażywane

Kuszyk jeden mały

Fajera wielka mało zażywana

Fajerka pomniejsza zażywana dużo

Miedniczka do umywania

Grzejaln[i]a miedziana rozgrzewać pościel

Deków miedzianych trzy

Rądle [sic!] trzy

Rynek dwie - jedna mniejsza, druga większa miedzianych, kociełek - to jest wszystko zażywane a kociełek zły, zepsowany

Alembik w którym jest garcy piętnaście o dwóch rurach, pokrywka u niego popsowana

Alembiczek w którym garcy pięć o dwóch rurkach ze wszystkiem dobry

Alembiczek w którym półtora garca o dwóch rurkach już dużo napsowany

Garcy browarnych dwa, u każdego rur trzy i te zażywane dużo

Kocieł wielki piwny

Kociełek mały drugi do szmelcowania chmielu, te kotły już zażywane

Moździerz z thuczkiem mosiężnym jeden

Mosiądz

Panew mosiężna już niedobra

Żelazne naczynie

Kocioł żelazny jeden

Panew żelazna już dużo zażywana

Patelnia żelazna zażywana

Patelnia itidem $^{48}$ żelazna zażywana

Patelnia itidem żelazna zła

Paneweczka mała

Rost żelazny

\footnotetext{
${ }^{48}$ Itidem-podobnie, również.
} 
Wilków żelaznych para

Sagon żelazny do kuchnie

Garków żelaznych trzy

Sprzęty domowe

Materacz karmazynowy sukienny i z wałem bez kutasów dużo zażywany

Kieca krymska biała zażywana pod materacz

Kiec prostych białych dwie zażywanych dużo

Kowelskich kilimów perskich trzy - jeden większy a dwa małe dużo zażywane

Sepet stary skórzany w którym namiot turecki fluoryzowany musułbasem podszyty czerwonym z bawełnianemu sznuramy

Szkatuła biała kielecką robotą

Zegarek alias $^{49}$ pektoralik malinki [sic!] złoty

Zegareczek mały stalowy

Barzo zły zegarek większy srebrny zły

Kompas cynowy magnetyczny zepsowany cum operculo tigneo Anni Millesimi Sexcentesimi Quinquagesimi terti ${ }^{50}$

\section{Książki różne}

Księga in folio ${ }^{51}$ Ioannis Iacobi „Rerum arabumq[ue]”

„Thesauri Possilia medicinae” w białą kompaturę oprawna

Kalepin w starą kompaturę in folio

„Politicarum quaestio[nes]” in octavo ${ }^{52}$ authore Junio ultembergensi Lasari Zesner Bibliopole ${ }^{53}$

M Deu Fragmentu [s. 671] Hotomani Iurisconsulti Frangogalia ${ }^{54}$ Anni Millesimi Quinqentesimi Septuagesimi Tertii

Ioannis Ludovici ${ }^{55}$ in octavo

„Viris Universitatis Rerum” in octavo, titulus „Iulii Caesaris omnia” qua extant ex Biblioteca [olim Fulvi] Ursini Romani Anno Domini MDXXIII

Książecka in quarto ${ }^{56}$ jak „Grammatyka” szaro oprawna titulus IHE Ekscelencjej

Książecka mała w szarej oprawie po niemiecku pisana „Majestas Claro Montana Virginis" Anno Domini Millesimi Septingentesimi Decimi Nona

„Klejnot Junosza” pod którym Familia Piastkowskich

${ }^{49}$ Alias - inaczej, czyli.

${ }^{50}$ Cum operculo tigneo Anni Millesimi Sexcentesimi Quinquagesimi Terti - z nakryciem drewnianym.

${ }^{51}$ In folio - format bibliograficzny używany do określenia wielkości książki. In folio - arkusz złamany raz, wysokość książki powyżej $35 \mathrm{~cm}$.

${ }^{52}$ In octavo - format bibliograficzny, wysokość książki ok. $25-35 \mathrm{~cm}$.

${ }^{53}$ Właśc. Lasarus Zetzner (1551-1616) - niemiecki wydawca i drukarz.

${ }^{54}$ Być może: François Hotman, Francogalia, Geneve 1576.

${ }^{55}$ Być może: Juan Luis Vives, Ioannis Ludovici Vivis Valentini Colloquia, Basilea 1553, lub idem, Ioannis Ludovici Vivis Valentini, ad veram sapientiam Introductio..., Coloniae 1559.

${ }^{56}$ In quarto - format bibliograficzny, wysokość książki ok. 20-25 cm. 
Mała książecka na kształt fascykułu w czerwonej oprawie starej sine titulo ${ }^{57}$

Stara książecka powydzierana in octavo titulus "Traedia Selecta"58 Anno Domini $M D L X V I I$

„Institutiones Iuris Civilis Divi Iustiniani Principis" 59 in octavo

Joachimi Mynsinger w białą kompaturę pargaminową oprawne, Londini MDCV

Książecka mała w pargamin biały obszyta titulo Ioannis Karvini ${ }^{60}$

Konstytucyje w starej oprawie ab Anno Millesimo Quingentesimo defektowa

Kronika defektowa w starej kompaturze titulus „Compendium Crom[?] Poloniae" 61 versis retropaginis ${ }^{62}$

Konstytucyje defektowe w turecki papier oprawne

Jest opposita manus Niebosczyka Jegomości Pana Miłoszewskiego Anno Domini Millesimo Septingentesimo Decimo Nono

Konstytucyje w szarą kompaturę oprawne defektowe, klauzury i narożniki mosiężne

Konstytucyje defektowe w biały papier oprawne ab Anno Millesimo Sexcentesimo Undecimo zaczynające się, nie skończone

Konstytucyje defektowe w lazurowy papier oprawne

Konstytucyje różne nie kompaktowane, sznurkiem obwiązane w kompaturze czerwonej

Książka in folio, w turecki papier oprawna, titulus „Wizeronek świętej doskonałości”63

Książka in quarto, szara kompatura, titulo „Processus Iudicarius”64

Książka in quarto, szara kompatura sine titulo do gospodarstwa należąca, na ostatku manuscript ${ }^{65}$ lekarstw różnych

Księga in folio w szarej kompaturze titulo „Historia o krucjatach”66

Księga wielka w białym pargaminie [s. 672] titulus „Aranasy kierkon?”67

Statut koronny ${ }^{68} \mathrm{w}$ zielonym pargaminie

Książka bez oprawy, in folio, titulus „Ogród fiałkowy Najświętszej Panny Maryi na Piasku kwitnący"69

${ }^{57}$ Sine titulo - bez tytułu.

${ }^{58}$ Być może: Aeschylos, Sophocles, Euripides, Traedia selecta, Geneva 1567.

${ }^{59}$ Być może: Justinian, Institutiones iuris civilis, Venetiis 1558.

${ }^{60}$ Być może książka autorstwa: Ioannis Carvini.

${ }^{61}$ Być może: Martini Cromeri de origine et rebus gestis Polonorum libri XXX, Basilea 1555 lub 1568.

${ }^{62}$ Versis retropaginis - wersja paginowana od tyłu.

${ }^{63}$ Marcin Ignacy Frankowic, Wizerunek świętey doskonałości..., Kraków 1718.

${ }^{64}$ Ulrich Fabricius, Processus Iudicarius, Basilea [1542?].

${ }^{65}$ Manuscript - łac. manuscriptum - rękopis.

${ }^{66}$ Ludwik Maimburg, Historya o krucjatach na wyzwolenie Ziemie Świętey..., thum. Andrzej Wincenty z Unichowa Ustrzycki, Kraków 1707, także 1708.

${ }^{67}$ Tytuł niemożliwy do zidentyfikowania. Skojarzenie z: Athanasius Kircher (1602-1680), niemiecki teolog, autor ponad 40 książek.

${ }^{68}$ Prawdopodobnie: Jan Herburt, Statuta Regni Poloniae in ordinen alphabeti, Kraków 1563 lub jedno z kilku późniejszych wydań.

${ }^{69}$ Mikołaj Grodzinski, Ogród fiiołkowy karmelitański na Piasku przy Krakowie [...] od Maryjej Panny [...] ozdobnie wysadzony..., Kraków 1673. 
„Synodus Dyocyzyana” Illustrisimi Łubi[e]ński ${ }^{70}$

„Peregrynacya” Radziwiłła ${ }^{71}$ in quarto

Książka odarta in octavo „Ioannis Ludovici vivis”72

Książka odarta in octavotitulus „Pharaginis actionum Iuris” ${ }^{\text {"73 }}$

Książka odarta in octavo o Najświętszej Bogurodzice Pannie

Książecka titulo „Odrobiny stołu królewskiego" 74 in octavo

Kałamarz na papiry podróżne

Książecka Alberti Magni ${ }^{75}$ po łacinie

Herbarz Potockiego ${ }^{76}$ in folio

Księga Aekonomiczna in folio edycyjej nieb[oszczy]ka Haura ${ }^{77}$, tytuł i regestr wydarty

Manuscript titulus „Piastkowskich klejnot” in quarto

Książka „Junosza klejnot”78 in quarto

Manuscript „Orbis Poloni Junosza seu annes”, in quarto

Kalendarze in octavo cztery

Sekstern manusriptu titulus „Krótka Synopsis”

Książka odarta manuscript defektowana, której była kompatura z kitajki lazurowej

„Epistola” Illustrissimo Załuski ${ }^{79}$ dedicata $^{80}$

Książka odarta o wyderkaffach ${ }^{81}$

„Historyja Najjaśniejszych Monarchów czterech polskich” przez Jana Duczewskiego napisana, manuscript

„Informacyja skąd Dunczowie wyśli”, manuscript

Poprawa praw i swobód Statutu spisanego

Puzderko do kałamarzyka podróżnego z zameczkiem bez klucza

${ }^{70}$ Kazimierz Łubieński, Synodus dioecesana ..., Kraków 1711.

${ }^{71}$ Mikołaj Krzysztof Radziwiłł „Sierotka”, Peregrynacia abo pielgrzymowania do Ziemie Świętej, wyd. 1607 lub kolejne: 1611, 1617, 1628, 1683.

${ }^{72}$ Być może: Juan Luis Vives, Ioannis Ludovici Vivis Valentini Colloquia..., Basileae 1553 lub idem, Ioannis Ludovici Vivis Valentini, ad teram sapientiam Introductio..., Coloniae 1559.

${ }^{73}$ Być może: Jan Cervus, Farrago actionum civilium ..., Kraków 1531 lub późniejsze wydania.

${ }^{74}$ Ambroży Nieszporkowicz, Odrobiny z stołu królewskiego królowy nieba y ziemi Nayświętszej Bogarodzicy Panny Maryi..., [Kraków] 1683 lub 1720.

${ }^{75}$ Albertus Magnus - św. Albert Wielki (1193/1205-1280), teolog dominikański, filozof scholastyczny, doktor Kościoła.

${ }^{76}$ Wacław Potocki, Poczet herbów szlachty Korony Polskiej i Wielkiego Xięstwa Litewskiego..., Kraków 1696.

${ }^{77}$ Jakub Kazimierz Haur, Oekonomika ziemiańska generalna..., Kraków 1675 lub: Ziemiańska generalna oekonomika ..., Kraków 1679.

${ }^{78}$ Jan Łazowski, Kleynot Junosza, pod którym familia Piaskowskich z Herbarza Paprockiego..., b.m. 1683 .

${ }^{79}$ Być może: Andrzej Chryzostom Załuski, Epistolae [...] Epistoporum Historico-Familiarum ..., Brunsbergae 1709.

${ }^{80}$ Dedicata - przypisana.

${ }^{81}$ Być może: Marcin Śmiglecki, O lichwie i o wyderkach, czynszach, spólnych zarobkach, najmach, arendach i o samokupstwie krótka nauka, Kraków 1607 lub jedno z późniejszych wydań. 
Książka titulus „Nauki chrześcijańskie”82

Łochowski ${ }^{83}$ do rozgraniczania należący we środku dużo zepsowany

Konfederacyja drukowana

Konie

Koni gniadych wo[j]skowych zostało sześć, z tych zdechło zaraz dwa, bernardynom na Stradom ${ }^{84}$ dałam jednego

Ogier siwy, którego za żywota swego deklarował Jegomości Panu patronowi lubelskiemu Niebosczyk mój mąż, tegom zaprowadziła do Jegomości Pana Miłoszewskiego starosty kleszczowskiego, ten się został u niego, nie oddał

Koń gniady wierzchowy na którym Niebosczyk jeździł, ten poszedł in pignus Jegomości Panu patronowi lubelskiemu in recompensam ${ }^{85}$ siwego ogiera, który [s. 673] do niego doszedł

Koń kary, który był barzo stary zdech

Koń gniady słuszny zdech od starości

Klacz szpakowata wielka

Jest klacz pleśniwa zdechła

Klacz siwych para

Klaczy trzy białych - z tych przedałam jednę zdychawiczałą za złotych piętnaście, druga dostała się Jegomości Panu patronowi krakowskiemu, trzecia jest klacz robotna

Biała klacz tarantowa zdechła

Źrebicz młodych białych dwie

Ogierek robotny

Ślepy koń srokaty co na nim syn jeździ

Szorów sześć złych

Obora

Krów było szesnaście, z tych zabiłam dla ubogich jednę

Wołów było alias cielców młodych par trzy, dałam z nich do reformatów ${ }^{86}$ za duszę Niebosczyka męża par dwie, chłopu parę jednę alias trzecią jałowic, cztery bujaków

Trzoda

Świni było zostało dwadzieścia i sześć, te wyzdychały, tylko ich zostało dziewięcioro

Gęsi dwadzieścia i dwoje

Indyk dziesięcioro

Kur trzydzieści troje

\footnotetext{
${ }^{82}$ Być może: Andrzej Chryzostom Załuski, Nauki chrześcijańskie z ksiag Augustyna Świętego..., Warszawa, po 1686.

${ }^{83}$ Stanisław Łochowski, Processus iudiciarius granicialis Regni Poloniae, Kraków 1641.

${ }^{84}$ Bernardyni na Stradomiu - klasztor ufundowany w Krakowie przez kard. Zbigniewa Oleśnickiego w $1453 \mathrm{r}$.

${ }^{85}$ In recompensam - jako wyrównanie straty, kompensacja.

${ }^{86}$ Reformaci - zakon obecny w Krakowie od 1625 r., początkowo na przedmieściu Garbary, po 1672 r. przy ul. Reformackiej.
} 
Sprzęty różne gospodarskie

Wózek bez przykrycia francuski, ten barzo zły

Wózek kryty i ten barzo zły

Wozów dwa okowanych gospodarskich barzo złych

Sanie nowo malowane wielkie dobre

Sanki parokonne małe i dobre

Bron par trzy, ale niezupełnie grabiami nabite, reparacyji potrzebują

Naczynie ciesielskie do reparacyji domowych

Piła traczka jedna

Pił dwie ręcznych połomanych i lutowanych

Piłek dwie małych jednoręcznych

Topor ciesielski dwuraźny jeden

Siekier dwie wyrobionych

Toporek ciesielski

Hynak jeden

Łańcuch jeden

Łańcuch pomniejszy drugi

Żelazo z wiadra, to jest obręcze żelazne

Dłuto, cieślica, ośnik to wszystko stare, potrzebują ustalenia

Świder teblowy jeden

Węgielnica żelazna

Łopat okowanych do przebierania przekop dwie

Siekaczów do kapusty na styliszkach drewnianych trzy

Lewar do wozu formański

Radlica do przeorania przekop.

Te rzeczy wszytkie wyżej specyfikowane są rzetelnie spisane i ad Acta praesentia Castrensia Capitanealia Cracoviensia per oblatam $^{87}$ podane i juramentem [s. 674] przeze mnie stwierdzone, na co się dla lepszej wagi i wiary przy pieczęci Domu mego ręką własną podpisuję. Elżbieta z Trzebini Lubieniecka locus sigilli ${ }^{88}$.

Et hic in continenti in verificationem praemissorum supra scripta offerens Magnifica Helisabeth de Trzebinia ultimi voti Magnifici Vladislai de Lubieniec Lubieniecki Camerarii Granicialis Districtus Sandecensis seu Czchoviensis prestitit coram eodem Officio et Actis praesentibus Castriensibus Capitanealibus Cracoviensibus, Iuramentum corporale, flexis genibus ad imaginem Crucifixi Domini Nostri Jesu Christi observans solennitate iuramentorum in eam Iuramenti Rotham ${ }^{89}$.

${ }^{87}$ Ad Acta praesentia Castrensia Capitanealia Cracoviensia per oblatam - do akt obecnych grodzkich starościńskich krakowskich do oblaty.

${ }^{88}$ Locussigilli - miejsce pieczęci.

${ }^{89}$ Et hic in continenti in verificationem praemissorum supra scripta offerens Magnifica Helisabeth de Trzebinia ultimi voti Magnifici Vladislai de Lubieniec Lubieniecki Camerarii Granicialis Districtus Sandecensis seu Czchoviensis prestitit coram eodem Officio et Actis praesentibus Castriensibus Capitanealibus Cracoviensibus, Iuramentum corporale, flexis genibus ad Imagine Crucifixi Domini Nostri Jesu Christi observata solennitate Iuramentorum in eam Iuramenti Rotham - I tu zawartość zgodnie z potwierdzoną prawdą wcześniejszych przesłanek poza pismami oferenta Wielmożna Elż- 
Ja Elżbieta przysięgam Panu Bogu Wszechmogącemu w Trójcy Świętej Jedynemu iż ten inwentarz rzeczy ruchomych po śmierci niegdy Jegomości Pana Jana Miłoszewskiego powtórniego męża mego pozostałych, który do akt grodzkich krakowskich podaję, jest wiernie, prawdziwie i sprawiedliwie spisany i nic nie zataiłam. Deo Omnipotente et Sacrosancta Jesu Christi Passione ita ipsam in praemissis adiuwante. Quod Iuramentum Officium praesens ab ipsa suscepit et actis suis ${ }^{90}$.

\section{Słowniczek wyrazów staropolskich i rzadziej używanych}

alembik, alembiczek - naczynie, przyrząd do destylacji cieczy, produkcji alkoholu awtowana - haftowana

aspiżek, aspisz - kamień półszlachetny używany do ozdoby, m.in. tabakierek, oprawy noży

blachmal - żużlowata masa pływająca po wierzchu roztopionego srebra; płatnerze pokrywali nią dla ozdoby zbroje i broń sieczną, służyła także jako pokrycie innych wyrobów metalowych

bujak - byk

burka - opończa wełniana lub pilśniowa

buzdyganik, buzdygan - gałka osadzona na krótkim drzewcu, znak władzy wojskowej

cieślica - siekierka ciesielska do wydrążania w drewnie fug, dziur itp.; tasak

dek - przykrycie, pokrowiec, dera

dublerowany - podwójny

dywdyk (dyftyk) - długa kapa na konia, najczęściej jedwabna, o szkarłatnej barwie, przetykana złotą nitką

dzierytka - najprawdopodobniej dziryt - krótka broń drzewcowa złożona ze stalowego grotu z zadziorami osadzonego na drzewcu

fajera, fajerka - przenośny piecyk lub naczynie do rozpalania ognia

fascykuł - zbiór luźnych akt powiązanych treściowo, zazwyczaj złożonych w okładzinach fluoryzowany - świecący

fuzja - ręczna broń palna o zapłonie skałkowym, potocznie: strzelba myśliwska garniec - miara objętości, dzieliła się na cztery kwarty

głownia - brzeszczot, klinga, główna część broni siecznej od rękojeści w dół gotowalnia - mebel, toaletka ze wszystkimi przyborami

grabki - widelec

bieta z Trzebini ostatnie małżeństwo z Wielmożnym Władysławem z Lubieniec Lubienieckim podkomorzym pogranicznym powiatu sądeckiego albo czchowskiego wypowiedziała przed tymże urzędem i aktami obecnymi Grodzkimi Starostwa Krakowskiego, przysięgą cielesną, na ugiętych kolanach na wizerunek ukrzyżowanego Pana naszego Jezusa Chrystusa, zwracając uwagę na tę rotę przysięgi przysiągł.

${ }^{90}$ Deo Omnipotente et Sacrosancta Jesu Christi Passione ita ipsam in praemissis adiuwante. Quod Iuramentum Officium praesens ab ipsa suscepit et actis suis - Boże Wszechmogący i święta męka Jezusa Chrystusa tak mi dopomóż. Tę przysięgę przyjął urząd do swoich akt. 
grzejalnia - naczynie blaszane napełnione gorącą wodą, stosowane do rozgrzewania ciała habowy płat - ozdoba chomąta; haba - grubsze białe sukno wyrabiane na Wschodzie hakownica - rodzaj strzelby o zapłonie lontowym, bez bagnetu hynak - tu: znaczenie nieznane, narzędzie gospodarskie jaszcz - drewniane naczynie np. na masło, bryndzę czy powidła jucht - skóra krowia, cielęca lub barania wygarbowana, używana często na wierzch obuwia

juki - torby, sakwy skórzane do przewożenia przedmiotów na koniu jurament - przysięga

kalepin (galepin) - wielki słownik lub wypisy z różnych dzieł kałamarz - pojemnik nie tylko na atrament, ale też pióro i papier kapturek - tu: blacha pokrywająca jelec pałasza, część konstrukcyjna rękojeści karabela - lekka ozdobna szabla noszona głównie podczas uroczystych okazji karwasz - naramiennik, nagolennik lub osłona dłoni; także: krótka szabla kieca - tu: odzież sukienna lub jedwabna na zbroję; płaszcz żołnierski kitajka - cienka tkanina jedwabna tkana splotem płóciennym, jednobarwna lub mieniąca się kompaktowany - oprawiony przez introligatora kompatura - oprawa książki w gruby papier lub pergamin do owijania ksiąg kruczek - tu: haczyk

krwawnik - tu: odmiana chalcedonu, inaczej karneol

kulbaka - drewniane siodło zwykle o wysokim tylnym łęku kutas - ozdoba szmuklerska w postaci pędzla z nici lub sznureczków kusz, kuszyk - naczynie do napoju, kubek, puchar kwarta - miara objętości $1 / 4$ garnca lawet, laweta - oparcie, na którym spoczywa działo, np. dwukołowy wóz lewar - prosty przyrząd mechaniczny do podnoszenia ciężarów lub jednoramienne urządzenie służące do naciągania cięciwy kuszy

ładownica - futerał na naboje łapcie - część karwasza (zob.) osłaniająca dłoń łęk - wygięta do góry część siodła, drewniany szkielet siodła macica perłowa - warstwa węglanu wapnia tworząca się na wewnętrznej powierzchni muszli, wyrabiano z niej ozdobne przedmioty

misiurka - rodzaj płaskiego hełmu o kształcie jarmułki, z którego spada żelazny czepiec osłaniający kark

moderunek - ogół rzeczy dla żołnierza lub konia

moździerz - tu: rodzaj armaty

multan - rodzaj pałasza pochodzący z Mołdawii (dawniej: Multany)

munsztuk, mosztuk - przyrząd do kiełzania koni

musułbas - tkanina bawełniana, używana szczególnie do podszywania opończ i namiotów muszkiecik, muszkiet - ręczna broń palna dużego kalibru, odpalana lontem, używana przez piechotę osnik, ośnik - strug, nóż prosty lub kabłąkowaty z dwoma trzonkami do oburęcznego ujęcia i strugania obręczy, kopyt końskich, podkuwania konia i robót kołodziejskich pałasz - broń sieczna sztychowa, pośrednia między mieczem a szablą 
patron - tu: obrońca sądowy, adwokat

pektoralik - mały zegarek do noszenia na piersiach

pistolety z mosiężnymi kapturkami - z mosiężną głowicą kolby

pleśniwa (maść konia) - siwa, cisawa, biało nakrapiana

podwodne konie - używane do podwody, czyli do wozu, furmanki

podpierścienie (podpiersienie) - rzemień w uprzęży przechodzący pod piersiami końskimi pomierny - proporcjonalny lub niewielki

półpięta - cztery i pół

prawda - tu: wypukło-wklęsłe naczyńko wkładane podczas robienia masła na maśnicę,

aby śmietana nie rozpryskiwała się

prochownica - puszka, róg na proch strzelecki

przekopa - wykop, rów, kanał

przystawka - tu: misa średniej wielkości, półmisek lub salaterka

radlica - pług lub część radła krusząca ziemię

rost - ruszt

rządzik, rząd - cała uprząż na konia, tj. siodło z czaprakiem i pokryciem wierzchnim, ozdobną uzdą, podpiersiem i podogoniem

sajdak, saydak - futerał, w którym mieścił się łuk z cięciwą i kołczan ze strzałami

salserka - tu: sosjerka

sekstern - zeszyt lub nieoprawna książka

sepet, sepecik - kufer, skrzynia z szufladkami i zamykanymi drzwiami

smaraszek - szmaragd

specyfikować - wyszczególniać, wyliczać

srokaty (koń) - pstrokaty, nakrapiany

szmelc, szmelcowany - szklista powłoka na metalu, glazura

szmelcowanie chmielu - gotowanie, warzenie

szory - rodzaj uprzęży na konia bez chomąta i kabłąka

sztuciec, tu: broń palna ręczna żłobkowana

sztuczki - ogniwa łańcucha

szturmak - tu: rodzaj strzelby z rurą szeroką u wylotu

tarantowa (klacz) - maści czarno-białej, czarno nakrapianej, cętkowanej

tebel - świder

traczka (piła) - rodzaj piły do drzewa o ukośnych zębach, wzdłuż słojów na deski

węgielnica - kątownica, kątownik

wilk - tu: podstawka żelazna używana w kuchni, na której układa się drewna lub wspiera rożen

wojłok - pilśń, twarda wełna, zbita na rodzaj bardzo grubego sukna; może być używany pod siodło

wychędożony - wyczyszczony, wyszorowany

zabieniec, żabieniec - kamień koloru żaby

zaklika - zapinka 


\section{BIBLIOGRAFIA}

\section{Źródla rękopiśmienne}

Archiwum Narodowe w Krakowie

Księgi grodzkie krakowskie, sygn. 29/5/800, 29/5/805, 29/5/817.

Księgi sądu podkomorskiego, sygn. 29/18/8-9.

\section{Źródla drukowane}

Inwentarze mieszczańskie z wieku XVIII z ksiag miejskich i grodzkich Poznania. T. 1: z lat 1700-1758. Oprac. Józef Burszta i Czesław Łuczak. Poznań: Państwowe Wydawnictwo Naukowe, 1962.

Słownik geograficzno-historyczny Królestwa Polskiego i innych krajów słowiańskich, t. 14. Wyd. Bronisław Chlebowski, Józef Krzywicki, Filip Sulimierski. Warszawa: Wyd. Gebethner i Wolff, 1895.

Uruski Seweryn: Rodzina. Herbarz szlachty polskiej, t. 11. Warszawa: Gebethner i Wolff, 1914.

\section{Opracowania}

Bardach Juliusz: Historia państwa i prawa Polski. T. 1: do połowy XV wieku. Warszawa: Państwowe Wydawnictwo Naukowe, 1964.

Danowska Ewa: Intercyzy, testamenty i inwentarze pośmiertne krakowskich mieszczan epoki nowożytnej jako źródła edycji. W: Teoria i praktyka edycji nowożytnych źródet w Polsce (XVI-XVIII w.). Red. Adam Perłakowski. Kraków: Historia Iagellonica, 2011, s. 219-226.

Danowska Ewa: Inwentarz pośmiertny rajcy krakowskiego Andrzeja Stanisława Krauza z 1702 r. „Rocznik Krakowski” 2007, R. 73, s. 95-106.

Danowska Ewa: O rzeczach doczesnych księdza kanonika. Inwentarz pośmiertny Michała hrabiego Ankwicza z 1786 r. „Nasza Przeszłość. Studia z dziejów Kościoła i kultury katolickiej w Polsce" 2008, t. 110, s. 107-128.

Dąbkowski Przemysław: Prawo prywatne polskie, t. 1. Lwów: Towarzystwo dla Popierania Nauki Polskiej, 1910.

Estreicher Karol: Bibliografia polska (stulecie XV-XVIII w układzie abecadłowym), Warszawa: Wydawnictwa Artystyczne i Filmowe, 1977.

Gajewska Mirosława: Wyposażenie w sprzęty mieszczańskie gospodarstw domowych Poznania $i$ Warszawy w XVIII wieku. Studia i Materiały z Historii Kultury Materialnej, t. 50, Wrocław, 1975.

Gloger Zygmunt: Encyklopedia staropolska ilustrowana. T. 1-4. Warszawa: Druk. P. Laskauera i W. Babickiego, 1900-1903.

Góralski Zbigniew: Urzędy i godności w dawnej Polsce. Warszawa: Ludowa Spółdzielnia Wydawnicza, 1984.

Inwentarz. W: Gloger Zygmunt: Encyklopedia staropolska ilustrowana, t. 2. Warszawa: Druk. P. Laskauera i W. Babickiego, 1901, s. 276-277.

Klonder Andrzej: Mienie godne szlachcica i mieszczanina w krajach Europy Środkowej z XVII wieku. „Kwartalnik Historii Kultury Materialnej” 2001, R. 49, nr 1-2, s. 81-94. 
Klonder Andrzej: Wszystka spuścizna w Bogu spoczywajacego. Majątek ruchomy zwyktych mieszkańców Elblaga i Gdańska w XVII wieku. Studia i Materiały z Historii Kultury Materialnej t. 68, Warszawa, 2000.

Kowecka Elżbieta: Inwentarze pośmiertne. „Mówią Wieki” 1988, nr 10, s. 9-15.

Kowecka Elżbieta: Mieszkania warszawskie z XIX wieku (do 1890). W: Elżbieta Balcerzak, Elżbieta Kowecka, Jerzy Kruppé: Wybrane problemy kultury materialnej miast polskich z XVIII i XIX wieku. Studia i Materiały z Historii Kultury Materialnej t. 56, Wrocław, 1983.

Kriegseisen Wojciech: Samorzad szlachecki w Małopolsce w latach 1669-1717. Warszawa: Państwowe Wydawnictwo Naukowe, 1989.

Kwaśniewicz Włodzimierz: 1000 słów o broni białej i uzbrojeniu ochronnym. Warszawa: Wydawnictwo Ministerstwa Obrony Narodowej, 1981.

Lepszy Leonard: Cech złotniczy w Krakowie. „Rocznik Krakowski” 1898, R. 1, s. 135-268.

Pośpiech Andrzej: Pułapka oczywistości. Pośmiertne spisy ruchomości szlachty wielkopolskiej z XVII wieku. Studia i Materiały z Historii Kultury Materialnej t. 64, Warszawa, 1992.

Pullat Raimo: Świat rzeczy mieszkańca Tallina w dobie Oświecenia. Kraków: Wydawnictwo Polskiej Akademii Umiejętności, 2018.

Słownik języka polskiego. T. 1-8. Oprac. Jan Karłowicz, Adam Kryński, Władysław Niedźwiedzki. Warszawa: Państwowy Instytut Wydawniczy (wyd. fotooffsetowe), 1952-1953.

Stoksik Janina Mirosława: Geometrzy małopolscy do końca XVIII wieku. Z dziejów geodezji i kartografii wielkoskalowej w Polsce. Kraków: Archiwum Narodowe w Krakowie, 2013.

Torecki Stanisław: 1000 słów o broni i balistyce. Warszawa: Wydawnictwo Ministerstwa Obrony Narodowej, 1982.

Turnau Irena: Słownik ubiorów. Tkaniny, wyroby pozatkackie, skóry, broń i klejnoty oraz barwy znane w Polsce od średniowiecza do poczatku XIX w. Warszawa: Wydawnictwo Naukowe Semper, 1999.

\section{STRESZCZENIE \\ Jana Miłoszewskiego dobytek doczesny. Inwentarz pośmiertny małopolskiego szlachcica z 1725 r.}

Poza testamentem, który pozostawiał zmarły, należało sporządzić inwentarz pośmiertny jego dóbr, aby uregulować w szczegółach podział spadku. Był to dokument o mocy prawnej, jego wykonanie ściśle określało prawo dotyczące danej warstwy społecznej, a obszerność zależała od stanu majątkowego zmarłego, ale też skrupulatności spisujących jego mienie.

Opublikowany inwentarz Jana Miłoszewskiego, skarbnika ciechanowskiego, komornika granicznego powiatu krakowskiego, zmarłego w 1725 r., został oblatowany w aktach grodzkich krakowskich. Obrazuje pozostawione mienie małopolskiego szlachcica świad- 
czące o stanie posiadania, m.in. sprzętów i różnego rodzaju broni, niezbędnych w życiu człowieka o jego statusie społecznym, a także przedmiotów związanych z gospodarstwem i życiem domowym. Warto zwrócić uwagę na obszerną bibliotekę, zapewne w dużej części odziedziczoną po przodkach rodziny, ale też przydatną dla pełnienia funkcji społecznych. Ze stanu posiadania opisanego w inwentarzu wywnioskować można, że był to majątek noszący znamiona dóbr gromadzonych przez pokolenia tej rodziny. Chociaż niewiele informacji zachowało się o J. Miłoszewskim, to szereg jego wpisów w księgach sądu podkomorskiego jako urzędującego komornika granicznego przyczynia się do możliwości usytuowania go w hierarchii małopolskiej szlachty.

\section{SUMMARY}

\section{The estate of Jan Miłoszewski. Estate inventory of the nobleman from Lesser Poland from 1725}

In addition to the testament left by the deceased, it was necessary to prepare an estate inventory of his possessions in order to finalise the details of the inheritance. This was a legally-valid document and its preparation was closely defined by the rights concerning a given level of society, with its range depending on the material status of the deceased as well as the meticulousness of the person preparing the inventory.

The published inventory of Jan Miłoszewski, treasurer of the Ciechanow area and a bailiff of the Krakow county who deceased in 1725, was recorded in the local Krakow records. It depicts the estate of the nobleman from Lesser Poland and testifies to the possession of, among others, equipment and various types of weapons, essential in the life of a man of his social status, as well as objects connected with agricultural and domestic life. It is worth paying attention to the vast library, almost certainly to a large extent inherited from previous generations of his family, but also useful for carrying out social functions. The material wealth described in the inventory suggests that it was collected by generations of the family. Although little information remains about J. Miłoszewski, the large number of entries he made in court records as a bailiff testify to his placement among the hierarchy of the gentry in Lesser Poland.

SŁOWA KLUCZOWE: Jan Miłoszewski, Małopolska, szlachta, inwentarz pośmiertny, kultura materialna

KEY WORDS: Jan Miłoszewski, Lesser Poland, gentry, estate inventory, material culture 